\title{
Nodulation and effective nitrogen fixation of Macroptilium atropurpureum (siratro) by Burkholderia tuberum, a nodulating and plant growth promoting beta-proteobacterium, are influenced by environmental factors
}

\author{
Annette A. Angus • Andrew Lee • \\ Michelle R. Lum • Maya Shehayeb • Reza Hessabi • \\ Nancy A. Fujishige • Shailaja Yerrapragada • \\ Stephanie Kano $\cdot$ Nannie Song $\cdot$ Paul Yang • \\ Paulina Estrada de los Santos • Sergio M. de Faria • \\ Felix D. Dakora • George Weinstock • Ann M. Hirsch
}

Received: 9 October 2012 / Accepted: 7 January 2013 /Published online: 26 January 2013

(C) Springer Science+Business Media Dordrecht 2013

\begin{abstract}
Background and aims Burkholderia tuberum STM678 was isolated from a South African legume, but did not renodulate this plant. Until a reliable host is found, studies on this and other interesting beta-rhizobia cannot advance. We investigated $B$. tuberum STM678 ${ }^{\mathrm{T}}$, s ability to induce $\mathrm{Fix}^{+}$nodules on a small-seeded, easy-topropagate legume (Macroptilium atropurpureum). Previous studies demonstrated that B. tuberum elicited
\end{abstract}

Responsible Editor: Hans Lambers.

Electronic supplementary material The online version of this article (doi:10.1007/s11104-013-1590-7) contains

supplementary material, which is available to authorized users.

A. A. Angus - M. Shehayeb - R. Hessabi - N. A. Fujishige

S. Kano $\cdot$ N. Song $\cdot$ P. Yang $\cdot$ A. M. Hirsch

Department of Molecular, Cell, and Developmental

Biology, University of California,

Los Angeles, CA 90095, USA

A. Lee

Department of Microbiology, Immunology, and Molecular Genetics, University of California,

Los Angeles, CA 90095, USA

A. M. Hirsch

Molecular Biology Institute, University of California,

Los Angeles, CA 90095, USA either $\mathrm{Fix}^{-}$or $\mathrm{Fix}^{+}$nodules on siratro, but the reasons for this difference were unexplored.

Methods Experiments to promote effective siratro nodule formation under different environmental conditions were performed. B. tuberum STM678 ${ }^{\mathrm{T}}$,s ability to withstand high temperatures and desiccation was checked as well as its potential for promoting plant growth via mechanisms in addition to nitrogen fixation, e.g., phosphate solubilization and siderophore

M. R. Lum

Biology Department, Loyola Marymount University,

Los Angeles, CA 90045, USA

S. Yerrapragada

Baylor College of Medicine, One Baylor Plaza,

Houston, TX 77030, USA

P. Estrada de los Santos

Departamento de Microbiología, Escuela Nacional de

Ciencias Biológicas, Instituto Politécnico Nacional,

Prolongación de Carpio y Plan de Ayala,

México, DF 11340, Mexico 
production. Potential genes for these activities were found in the sequenced genomes.

Results Higher temperatures and reduced watering resulted in reliable, effective nodulation on siratro. Burkholderia spp. solubilize phosphate and produce siderophores. Genes encoding proteins potentially involved in these growth-promoting activities were detected and are described.

Conclusions Siratro is an excellent model plant for $B$. tuberum STM678 ${ }^{\mathrm{T}}$. We identified genes that might be involved in the ability of diazotrophic Burkholderia species to survive harsh conditions, solubilize phosphate, and produce siderophores.

Keywords Siratro $\cdot$ Burkholderia $\cdot$ Abiotic stress .

Phosphate solubilization $\cdot$ Siderophore

$\begin{array}{ll}\text { Abbreviations } \\ \text { hpi } & \text { hours post-inoculation } \\ \text { dpi } & \text { days post-inoculation } \\ \text { CAS } & \text { chrome azurol S }\end{array}$

\section{Introduction}

Burkholderia tuberum STM678 ${ }^{\mathrm{T}}$, the major focus of this study, and other nitrogen-fixing members of the Burkholderiaceae have been isolated not only from a broad range of plant species, but also from various parts of the world-especially South Africa, Brazil, and

S. M. de Faria

Embrapa Agrobiologia,

Seropédica 23890-000 RJ, Brazil

F. D. Dakora

Chemistry Department, Tshwane University of Technology, Arcadia Campus, 175 Nelson Mandela,

Drive Private Bag X680,

Pretoria 0001, South Africa

G. Weinstock

Department of Genetics,

Washington University School of Medicine,

St. Louis, MO 63110, USA

A. M. Hirsch $(\bowtie)$

University of California-Los Angeles (UCLA),

621 Charles E. Young Drive South,

Los Angeles, CA 90095-1606, USA

e-mail: ahirsch@ucla.edu
Australia, three major centers of biological diversity (Gyaneshwar et al. 2011). The three other Burkholderia strains included in this study are B. unamae MTl-641 ${ }^{\mathrm{T}}$, B. silvatlantica SRMrh20 ${ }^{\mathrm{T}}$, and B. silvatlantica PVA5. They were isolated from both legume and non-legume plants, and all fix atmospheric nitrogen into ammonia (Table 1). Of these four, only B. tuberum nodulates legumes, but so far a model plant for the detailed study of this nitrogen-fixing, betaproteobacterial species has not been developed. Other legume-nodulating Burkholderia species include $B$. phymatum STM815 ${ }^{\mathrm{T}}$ (Vandamme et al. 2002), $B$. nodosa $\mathrm{Br} 3437^{\mathrm{T}}$, Br3641, Br2470 (Chen et al. 2007), and a number of B. mimosarum strains (Chen et al. 2006). The latter three species nodulate Mimosa spp. effectively and have closely related nodulation $(\operatorname{nod} A)$ and nitrogenase-encoding (nifH) genes. In contrast, the B. tuberum STM $678^{\mathrm{T}}$ nodA $(<75 \%)$ and $n i f H$ genes are distantly related ( $90 \%$ gene identity) to the comparable genes from the Mimosa-nodulating strain B. phymatum STM815 ${ }^{\mathrm{T}}$ (Gyaneshwar et al. 2011).

Vandamme et al. (2002) were the first to name and describe the taxonomic position of B. tuberum STM678 ${ }^{\mathrm{T}}$, which was isolated from the South African legume Aspalathus carnosa (tribe: Crotalarieae). However, this species has not yet been shown to nodulate its original host (see history in Elliott et al. 2007a and Gyaneshwar et al. 2011). Thus, Moulin et al. (2001) used siratro (Macroptilium atropurpureum, Phaseoleae), which is nodulated by a large number of alpha-rhizobial strains (Vincent 1970; Pueppke and Broughton 1999) to demonstrate that B. tuberum STM $678^{\mathrm{T}}$ could nodulate legumes. However, the siratro nodules that formed were reported as Fix (ineffective in nitrogen fixation) and only partially infected. At the same time, B. tuberum STM $678^{\mathrm{T}}$ was shown to have the nodulation gene $\operatorname{nod} A$, as well as two copies of $\operatorname{nodC}$ (Moulin et al. 2001), indicating that this strain had the potential to nodulate legumes. Later, Elliott et al. (2007a) reported that B. tuberum STM678 ${ }^{\mathrm{T}}$ developed $\mathrm{Fix}^{+}$(capable of nitrogen fixation) nodules not only on four species of Cyclopia (Podalyrieae), another genus of South African legumes that grows in the acidic soils of the fynbos, but also on siratro plants grown in glass tubes at $26^{\circ} \mathrm{C}$. These higher temperatures may be closer to the conditions encountered in the wild by the South African hosts and this legume. Siratro normally grows in moist, subtropical to tropical regions, but numerous studies have demonstrated that it is much more tolerant of dryness than other 
Table 1 Strains and plasmids used in this study

\begin{tabular}{|c|c|c|}
\hline Strains & Relevant characteristics & Source or reference \\
\hline $\begin{array}{l}\text { Rhizobium tropici UMR1899 } \\
\text { (CIAT899) }\end{array}$ & Acid tolerant. & Graham et al. 1982,1994 \\
\hline Burkholderia tuberum STM678 & $\begin{array}{l}\text { Wild-type. Isolated from Aspalathus carnosa nodules } \\
\text { in South Africa; nodulates Cyclopia spp. effectively. }\end{array}$ & $\begin{array}{l}\text { Moulin et al. 2001; Vandamme } \\
\text { et al. 2002; Chen et al. } 2003 .\end{array}$ \\
\hline Burkholderia tuberum TnGFP & $\mathrm{GFP}^{+}, \mathrm{Tet}^{\mathrm{R}}$ derivative of STM678. & Elliott et al. 2007a \\
\hline B. unamae MTI- $641^{\mathrm{T}}$ & Wild-type. Isolated from maize and sugarcane in Mexico. & Caballero-Mellado et al. 2004 \\
\hline B. silvatlantica PVA5 & Wild-type. Isolated from roots of Gleditisia tricanthos in Brazil. & de Faria et al. 1999. \\
\hline B. silvatlantica $\mathrm{SRMrh} 20^{\mathrm{T}}$ & Wild-type. Isolated from maize and sugarcane in Brazil. & Perin et al. 2006. \\
\hline
\end{tabular}

Plasmids

pHC60 GFP-plasmid, Tet $^{\mathrm{R}}$

Cheng and Walker 1998.

legumes or various grass species (Ahmed and Quilt 1980; Sheriff and Ludlow 1984; Ohashi et al. 2000). Siratro survives drought because of its long taproot, which reaches distant water sources (Sheriff and Ludlow 1984). It also tolerates both acid (pH4.5) and alkaline soils $(\mathrm{pH}$ 8.5) (http://www.tropicalforages.info/key/Forages/ Media/Html/Macroptilium_atropurpureum.htm). Although Rhizobium-induced siratro nodulation and growth was improved at higher temperatures $\left(26^{\circ} \mathrm{C}\right.$ or greater), these traits were nonetheless still dependent on the inoculum employed (Herridge and Roughley 1976).

Because we observed that effective nodulation of siratro by B. tuberum STM $678^{\mathrm{T}}$ occurred sporadically at $21 / 22{ }^{\circ} \mathrm{C}$, our objective was to establish whether temperature and other environmental factors could influence the ability of this bacterial species to establish $\mathrm{Fix}^{+}$nodules in a predictable way, with the ultimate goal of using this legume as a model system for studying host responses and for future mutant screening experiments. Lima et al. (2009) in a survey of nitrogen-fixing bacteria from various soils under different land uses in the Western Amazon region examined edaphic factors such as $\mathrm{Ca}^{2+}, \mathrm{Mg}^{2+}, \mathrm{Cu}^{2+}$, base saturation, exchangeable bases, as well as $\mathrm{pH}$ on siratro nodulation. Similarly, soil $\mathrm{pH}$, phosphate, and $\mathrm{CaCO}_{3}$ content and granulation were found to influence rhizobial nodulation of siratro and Mimosa (Mishra et al. 2012). Both studies concluded that this small-seeded legume is a valuable plant for trapping both alpha- and beta-rhizobia.

We compared siratro nodulation by B. tuberum with that induced by Rhizobium tropici CIAT899, which is reported to be tolerant of acid soils and high concentrations of aluminum (Graham et al. 1982). In this study, we investigated temperature, desiccation, and artificial substrate type, each of which potentially could dictate effective nodulation of siratro by $B$. tuberum STM678 ${ }^{\mathrm{T}}$ under laboratory conditions. The fact that Elliott et al. (2007a) grew seedlings in $30 \mathrm{~mL}$ glass tubes suggests that siratro root nodulation was not negatively affected by light as has been observed for some legumes, e.g., Pisum sativum (van Brussel et al. 1982) and Lotus japonicus (Suzuki et al. 2011), so we did not examine this parameter in our studies.

In addition to agar-based cultures, we employed mixtures of perlite, vermiculite, and sand in both open containers and in closed Magenta jars, the latter with small holes drilled into the tops because closed containers often accumulate ethylene, which inhibits nodulation (Lee and LaRue 1992). We also utilized Vigna unguiculata (cowpea) as a host because it is reported to be nodulated by both B. tuberum (F.D. Dakora, personal communication) and $R$. tropici (HernandezLucas et al. 1995). Also, because many bacteria promote growth via mechanisms other than nitrogen fixation, we examined whether B. tuberum STM $678^{\mathrm{T}}$ and three additional non-nodulating, but nitrogen-fixing Burkholderia species were able to secrete siderophores and to solubilize phosphate, two common mechanisms of plant growth promotion. Although $B$. unamae has already been shown to have many plant growth-promoting activities (Caballero-Mellado et al. 2007; Castro-González et al. 2011), we included it in our analysis for comparison.

Lastly, we looked for DNA sequences in the recently sequenced genomes of four plant-associated Burkholderia species (Table 1) that might be responsible for their performance under environmental stress. These include such traits as the ability to: 1) synthesize trehalose, a disaccharide with an unusual $\alpha, \alpha$ 1-1 
linkage between two glucose molecules, which is synthesized following desiccation or temperature stress by several alpha-rhizobia including Bradyrhizobium japonicum and Sinorhizobium meliloti (Streeter and Gomez 2006); 2) solubilize phosphate from forms that have limited solubility (Rodríguez et al. 2006); and 3) produce siderophores for obtaining iron from soil environments (Andrews et al. 2003). The presence of these traits as well as the ability to induce nitrogenfixing nodules make the siratro- $B$. tuberum system an important new model system to study various facets of the interaction between plants and symbiotic microbes, particularly the beta-rhizobia.

\section{Materials and methods}

Culture of bacteria and plants

The bacteria used in this study are listed in Table 1 . The plasmid pHC60 was mobilized into $R$. tropici CIAT899 using a triparental mating. For routine culture, the Rhizobium strains were grown either on TY or RDM (Vincent 1970) containing $10 \mu \mathrm{g} / \mathrm{mL}$ tetracycline (tet) to select for the plasmids, whereas the Burkholderia strains were grown on LB without salt or on YEM with or without $10 \mu \mathrm{g} / \mathrm{mL}$ tet. All bacteria were grown at $30^{\circ} \mathrm{C}$.

Seeds of $M$. atropurpureum were scarified for 12 min. using a scarifying cup (Brigham and Hoover 1956) prior to surface-sterilization. V. unguiculata subsp. unguiculata (PI339603) seeds were not scarified. Siratro seeds were first briefly washed with $95 \%$ ethanol for $5 \mathrm{~min}$. and then sterilized in a $50 \mathrm{~mL}$ conical centrifuge tube with full-strength commercial bleach on a rotating platform for 35-45 min. Five rinses of sterile water followed the bleaching step with the last rinse overnight. Cowpea seeds were placed in $10 \%$ bleach for $10 \mathrm{~min}$ after the initial $95 \%$ ethanol step, and also copiously rinsed with sterile water after sterilization. The sterilized seeds were placed on water agar (1\%) for 3 days in the dark to assess germination and sterility before planting. For seeds to be sown in Magenta jars, autoclaved perlite:vermiculite (1:1 by volume) or perlite:vermiculite:sand (1:1:1 by volume) watered with $1 / 4$ strength Hoagland's solution minus $\mathrm{N}$ was utilized. Magenta jar tops had holes drilled into them, and the holes were covered with sterile rayon adhesive film (AeraSeal, Excel Scientific, Wrightwood, CA) to permit airflow. The entire apparatus was autoclaved before seed planting. When plants touched the top of the Magenta jar, an autoclaved extender consisting of a Magenta jar unit with one end sawed off was added to the system to allow further shoot elongation.

Seeds were also sown directly after sterilization in autoclaved containers half-filled with either perlite: vermiculite (1:1 by volume) or a mixture of sand: perlite:vermiculite (1:1:1 by volume) watered with $1 / 4$ strength Hoagland's solution minus N. The moisture in the dishpans was monitored with a soil moisture meter (General Specialty Tools \& Instruments; Model DSMM500) to give an initial reading of $10-15 \%$, the pans were weighed, and once a week, $1 / 4$ strength Hoagland's solution minus $\mathrm{N}$ was added to the dishpans to the same weight to restore the moisture levels.

For the studies in $30 \mathrm{~mL}$ culture tubes, either Jensen's or $1 / 4$ strength Hoagland's solution minus $\mathrm{N}$ media were used for agar slants (1 \% Plant Agar, PhytoTechnology Laboratories, Shawnee Mission, $\mathrm{KS}$ ), and the bottoms of the tubes were covered with aluminum foil. Two siratro seeds were planted after the sterilization procedure per tube and inoculated immediately with $1 \mathrm{~mL}$ of $10^{6} / \mathrm{mL}$ bacteria resuspended in sterile water or phosphate-buffered saline after centrifugation. For the dishpans, 100$150 \mathrm{~mL}$ of inoculum were added, whereas $20 \mathrm{~mL}$ were used for the Magenta jars and the polypropylene pots.

\section{Microscopy}

For confocal microscopy, GFP-labeled bacteria in association with plant roots and nodules were visualized using a Zeiss LSM 5 Exciter. Images were obtained with the Zeiss ZEN acquisition/imaging software using a $5 \times$ or $10 \times$ objective and excitation at $488 \mathrm{~nm}$ for observation of GFP, and $545 \mathrm{~nm}$ for observation of root autofluorescence.

Light microscopic analysis using epifluorescence was performed as described in Fujishige et al. (2008).

Temperature influence on bacteria and desiccation effects on bacteria and siratro

For the temperature studies, $10 \mu \mathrm{L}$ spots of lag/early $\log (13 \mathrm{~h}), \log (17 \mathrm{~h})$, and stationary $(40 \mathrm{~h})$ phase cultures of $B$. tuberum and $R$. tropici were diluted to a starting concentration of $\mathrm{OD}_{600}=0.1$ and then 
spotted in triplicate onto LB agar plates and incubated at temperatures of $30{ }^{\circ} \mathrm{C}, 37^{\circ} \mathrm{C}$, or $40^{\circ} \mathrm{C}$ for $24 \mathrm{~h}$.

For the desiccation studies, assays were set up according to the method described by Hugenholtz et al. (1995). Briefly, nitrocellulose filters $(0.45 \mu \mathrm{m}$ pore $)$ were sterilized under UV light for $24 \mathrm{~h}$ before spotting the center in triplicate with $100 \mu \mathrm{L}$ of each overnight bacterial culture $(17$ or $40 \mathrm{~h}$ ) diluted in fresh LB to $\mathrm{OD}_{600}=0.1$. Filters were placed inside standard-sized sterile petri dishes and were allowed to air-dry, then placed inside a desiccation chamber filled with fresh silica desiccant (Sigma) and sealed using a vacuum line. The filters remained undisturbed within the chamber for $24 \mathrm{~h}$, after which they were transferred with a sterile forceps onto fresh LB agar plates and incubated at $30{ }^{\circ} \mathrm{C}$ for 4 days to recover desiccationresistant strains.

For the in vivo studies on water-stress effects, siratro plants were grown in sterilized perlite:vermiculte (dishpans) or perlite:vermiculte:sand (pots and Magenta jars) and watered with $1 / 4$ strength Hoagland's solution minus N. After 2 weeks of watering twice weekly, one set of B. tuberum-inoculated siratro plants kept the initial regime whereas the second set was watered every other week with the moisture content restored to ca. $15 \%$ at this time. Treatments representing the uninoculated as well as inoculated plants were observed for signs of desiccation stress after another 4-6 weeks.

Phosphate and siderophore assays

Phosphate solubilization by strains $B$. tuberum STM678 ${ }^{\mathrm{T}}$, B. unamae MTl-641 ${ }^{\mathrm{T}}$, B. silvatlantica strain PVA5, and B. silvatlantica strain SRMrh20 ${ }^{\mathrm{T}}$ was performed using both solid and liquid Pikovskaya (1948) (PVK) medium as modified by Xie et al. (2009). The liquid medium contained $36.7 \mathrm{mM} \mathrm{CaHPO}_{4}$. The bacterial strains were grown in liquid TY until stationary phase $(24-30 \mathrm{~h})$ at which time the cells were harvested by centrifugation $(8,000$ $\times \mathrm{g}, 10 \mathrm{~min}$ ), and the pellets washed with sterile water three times to remove traces of the TY medium. The cell pellets were diluted to $\mathrm{OD}_{600}=0.2$ in sterile water. For solid cultures, $10 \mu \mathrm{L}$ droplets were spotted onto plates, which were incubated at $30{ }^{\circ} \mathrm{C}$ for up to 10 days. The size of the colony and the clearing zone around the colony were measured. Quantification of the phosphate solubilized in liquid cultures was performed by use of the QuantiChrom Phosphate Assay kit (BioAssay systems; cat \# DIPI-500), recording the absorption at $620 \mathrm{~nm}$.

Both liquid and solid PVK medium were set to an initial $\mathrm{pH}$ of $7.55,6.53$, and 5.28, and then inoculated in triplicate. For the inoculated cultures, a $1 \mathrm{~mL}$ aliquot of a single culture of each strain was selected at random at 24 and $48 \mathrm{~h}$ intervals, centrifuged for $3 \mathrm{~min}$ to pellet the cells, and the $\mathrm{pH}$ of the supernatant was recorded. As a control, tubes of uninoculated medium of the same starting $\mathrm{pH}$ as the inoculated tube were prepared and treated the same as the test samples.

All four strains were also tested on solid PVK medium supplemented with $0.035 \%$ bromocresol purple, which has been shown to be an effective $\mathrm{pH}$ indicator ranging in color from purple at $\mathrm{pH} 7.0$ to yellow at pH5.0 (Yao and Byrne 2001). A triplicate set of the plates were inoculated with $10 \mu \mathrm{L}$ of 48 $\mathrm{h}$ grown cultures and incubated at $30{ }^{\circ} \mathrm{C}$. Colony size, zones of clearance, and zones of color diffusion were measured after $72 \mathrm{~h}$, and the ratio of zone of clearance to colony size calculated. The ratio was used to account for any difference in growth rate that occurred on media of different $\mathrm{pH}$ levels.

Chrome azurol S (CAS) agar medium devoid of nutrients was used as an indicator of the presence of siderophores using $0.9 \%(\mathrm{w} / \mathrm{v})$ agar as a gelling agent. The medium for a liter of the overlay medium included: CAS, $60.5 \mathrm{mg}$; hexadecyltrimetyl ammonium bromide (HDTMA or CTAB), $72.9 \mathrm{mg}$; piperazine-1,4bis(2-ethanesulfonic acid) (PIPES), $30.24 \mathrm{~g}$; and $10 \mathrm{~mL}$ of $1 \mathrm{mM} \mathrm{FeCl} \cdot 6 \mathrm{H}_{2} \mathrm{O}$ in $10 \mathrm{mM} \mathrm{HCl}$ (Schwyn and Neilands 1987). Bacteria were first grown in liquid TY until $\mathrm{OD}_{600}=0.1$, at which time $10 \mu \mathrm{L}$ droplets were spotted onto TY agar plates, allowed to dry, and incubated at $30{ }^{\circ} \mathrm{C}$ for 2 days. Molten CAS agar was poured over the bacterial spots grown on solid TY. The overlaid plates were observed for yellow to orange halos around the bacterial spots.

\section{Results}

Nodulation tests Earlier, we inoculated siratro plants that had been grown in dishpans containing perlite and vermiculite and watered twice weekly with nitrogenfree medium with $B$. tuberum STM678 ${ }^{\mathrm{T}}$, and found that at a day/night temperature of $22^{\circ} \mathrm{C} / 18^{\circ} \mathrm{C}$ only ineffective nodules formed on the roots (data not shown). Because Elliott et al. (2007a) reported the presence of 
$\mathrm{Fix}^{+}$nodules on siratro when the temperature was increased to $26{ }^{\circ} \mathrm{C}$ day $/ 22{ }^{\circ} \mathrm{C}$ night, we tested siratro nodulation not only at a higher temperature, but also under restricted water availability and in various substrates to see whether reliable nodulation and nitrogen fixation could be achieved with $B$. tuberum.

When dry weights and shoot lengths were measured after 6 weeks of growth in dishpans at higher temperatures and restricted water availability, a significant increase in the $B$. tuberum-inoculated plants compared to the uninoculated controls was observed using a one-way ANOVA with Tukey's post-hoc test (Fig. 1a). Nevertheless, under these conditions, plants were slow to show evidence of nitrogen fixation. It took approximately 4-6 weeks before the foliage turned a dark green. The shoot lengths of the $B$. tuberum-inoculated plants (Fig. 1b) in particular were
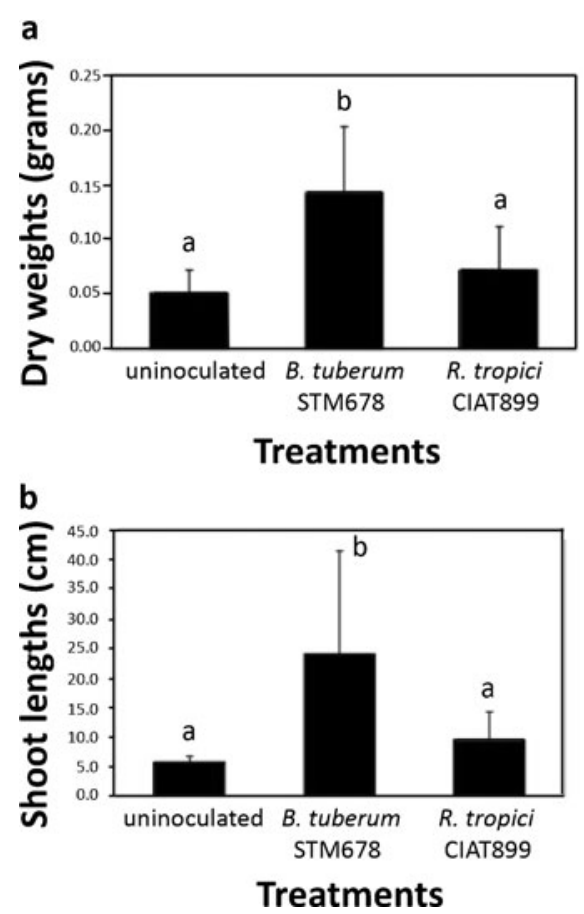

Fig. 1 Burkholderia tuberum STM678 ${ }^{\mathrm{T}}$ enhances plant biomass and siratro shoot length better than $R$. tropici CIAT899. The plants were harvested 6 weeks post inoculation, their shoot lengths measured, and then the plants were dried in a $65{ }^{\circ} \mathrm{C}$ oven for 3 days to obtain biomass measurements. B. tuberum STM678 ${ }^{\mathrm{T}}$ - or R. tropici CIAT899-inoculated plants showed an increase in dry weight (a) and shoot lengths (b) compared to uninoculated plants. Overall, B. tuberum-inoculated plants were more robust with respect to height, weight, and greenness compared to $R$. tropiciinoculated plants. One-way ANOVA with Tukey's post hoc test was done for comparison of the means. Different letters represent values that differ significantly, $P<0.01$ highly variable because not all plants developed the elongated internodes seen in Fig. 2a at the same time. Surprisingly, siratro plants inoculated with $R$. tropici and grown under the same conditions were small, had yellow leaves, short internodes, and did not develop nitrogen-fixing nodules (Figs. $1 \mathrm{~b}$ and $2 \mathrm{~b}$ ). Their average dry weight and stem length were also lower than those of the B. tuberum-inoculated siratro plants, but not statistically different than the values obtained for the uninoculated controls (Fig. 1).

Siratro nodules are determinate in that they lack a persistent nodule meristem (Hirsch 1992). A comparison of nodule development between GFP-labeled $R$. tropici CIAT899 and B. tuberum STM678 ${ }^{\mathrm{T}}$ demonstrated very little difference in the early nodulation stages. Both rhizobia elicited root hair deformation and entered the root hairs via infection threads (Fig. $2 \mathrm{~d}$ and e). $B$. tuberum-elicited nitrogen-fixing nodules were established on a well-developed siratro root system (Fig. 2c), and the shoots also expanded, producing climbing stems at about 6-8 weeks (Fig. 2a). Examination of the internal structure of siratro nodules showed that the nodule cells consisted of two types: interstitial cells devoid of bacteria and cells filled with green-fluorescing bacteria (Fig. 2f). This type of cell arrangement is characteristic of nodules that develop in response to infection thread penetration (Sprent 2007).

Plants in Magenta jars were nodulated within 3 weeks, and nitrogen fixation was also delayed. Under the same conditions, $R$. tropici CIAT899 again induced only ineffective nodules. We repeated the experiment in glass tubes and found that although the $B$. tuberum-inoculated plants formed $\mathrm{Fix}^{+}$nodules, the $R$. tropici-inoculated plants did not (data not shown). However, the $B$. tuberum-inoculated plants became water-stressed after 8 weeks in the glass tubes due to the drying of the agar. They also occasionally formed bacteria-free callus-like structures on the roots, even on the uninoculated plants, indicating that an agar-based screen in glass tubes might not be suitable for making meaningful conclusions about nodulation and nitrogen fixation ability.

Temperature and desiccation stress Because siratro is tolerant of dry conditions and nodulation by $B$. tuberum is enhanced at higher temperatures, we reasoned that the bacteria used to inoculate siratro might tolerate these abiotic stresses. B. tuberum and R. tropici were thus compared for their potential to tolerate 
Fig. 2 Effects of

B. tuberum STM678 ${ }^{\mathrm{T}}$ and $R$. tropici CIAT899 on siratro nodulation. a Healthy, siratro plant with elongated internodes and root nodules (arrows) had been inoculated with $B$. tuberum STM $678^{\mathrm{T}}$ and harvested 7.5 weeks post-inoculation Bar $=2 \mathrm{~cm}$. b Stunted, yellow siratro plant with numerous nodules (arrows) that had been inoculated with $R$. tropici CIAT899 and harvested 7.5 weeks postinoculation. $\mathrm{Bar}=2 \mathrm{~cm}$. c Pink nodules from a $B$. tuberum STM678 ${ }^{\mathrm{T}}$-inoculated siratro 6 weeks postinoculation. $B a r=5 \mathrm{~mm}$. d Infection thread formed within a siratro root hair by GFP-labeled $R$. tropici CIAT899. Bar $=50 \mu \mathrm{m}$. e Infection thread formed within a siratro root hair by GFP-labeled B. tuberum STM678 . Bar $=50 \mu \mathrm{m}$. f Young siratro nodule filled with GFP-labeled $B$. tuberum STM678 ${ }^{\mathrm{T}}$. Interstitial cells (arrows) are devoid of STM678 ${ }^{\mathrm{T}}$. Bar=1 mm
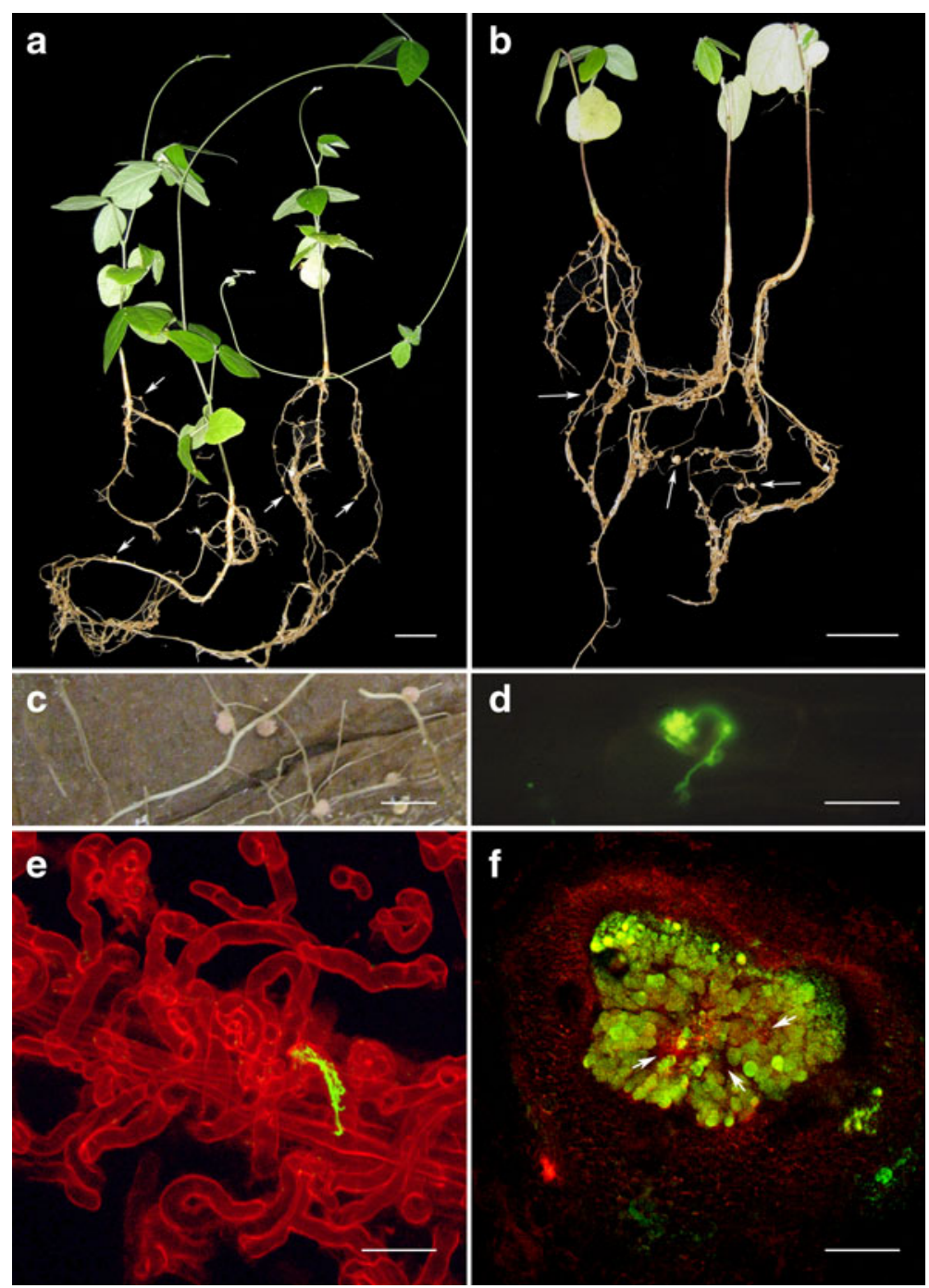

temperature and desiccation stress in culture. $R$. tropici had been shown earlier to acquire thermo-tolerance in response to high temperature exposure, although under such conditions, the bacteria did not fix nitrogen symbiotically (Michiels et al. 1994). We hypothesized that tolerance to severe stress could be one mechanism whereby $B$. tuberum could effectively nodulate siratro under adverse conditions. A number of possible mechanisms, such as trehalose synthesis, involvement of heat shock proteins, or glycine betaine/proline accumulation as well as exopolysaccharide production, may confer temperature and/or desiccation tolerance to Burkholderia.

Experimental analysis Incubation at temperatures of $30^{\circ} \mathrm{C}, 37^{\circ} \mathrm{C}$, and $40^{\circ} \mathrm{C}$, demonstrated that B. tuberum inoculated onto plates during the early growth phases, both lag and $\log$, exhibited limited growth at $30^{\circ} \mathrm{C}$ and no growth at the higher temperatures. In contrast, $R$. tropici at the same stages of growth grew at both $37^{\circ} \mathrm{C}$ and $40{ }^{\circ} \mathrm{C}$, confirming this species' tolerance to high temperatures. On the other hand, for cultures incubated at stationary phase, B. tuberum grew at all temperatures whereas $R$. tropici stationary phase cells survived only at $30{ }^{\circ} \mathrm{C}$.

Because the B. tuberum-inoculated plants formed effective nodules at higher temperatures, we reasoned that inoculated host plants might be more desiccationtolerant than the uninoculated plants. $R$. tropici was not included in these experiments because it induced a Fix ${ }^{-}$ nodule phenotype on siratro at $26{ }^{\circ} \mathrm{C}$. Following an additional 6-8 weeks of desiccation-simulating 
conditions (see Materials and Methods), the B. tuberuminoculated siratro plants were smaller than the unstressed B. tuberum-inoculated plants, but nonetheless were green and developed pink Fix ${ }^{+}$nodules, strongly suggesting that the bacteria were fixing nitrogen (Supplementary Information Fig. 1). Although many of the well-watered, inoculated plants produced vining internodes, fewer of the water-stressed inoculated plants did. By contrast, the uninoculated plants in both treatments were stunted, yellow, and lacked nodules.

In vitro studies investigating the desiccation tolerance of B. tuberum and R. tropici showed that both species were viable following simulated dry conditions (data not shown). Although $R$. tropici tolerated desiccation stress in early (exponential) growth phase and late (stationary) phase cultures, B. tuberum exhibited the most robust recovery from desiccation stress when in the stationary growth phase. One explanation for both the thermal and desiccation tolerance results reported here may be the overall slower growth of B. tuberum STM678 ${ }^{\mathrm{T}}$ compared to R. tropici CIAT899 and hence longer recovery time.

Genome analysis Because only a draft genome of $R$. tropici CIAT899 exists (Pinto et al. 2009), we could not make comparisons between it and the Burkholderia species with regard to specific gene sequences. In some cases, we utilized other Rhizobium genomes to make the comparison between alpha- and beta-rhizobia.

We hypothesized that trehalose, two glucose molecules held together by a glycosidic $\alpha-(1,1)$ bond and important in temperature and desiccation tolerance in alpha-rhizobia, may also be significant for stress adaptation in B. tuberum. Bradyrhizobium japonicum possesses three different trehalose biosynthetic pathways: 1) from UDP-glucose and glucose-6-phosphate via the enzyme trehalose 6-phosphate synthase (TPS; EC:2.4.1.15; otsA); 2) from the conversion of maltooligosaccharides to maltooligosyl trehalose via the enzyme maltooligosyl trehalose synthase (MOTS; EC:5.4.99.15; treY); and 3) from the direct catalysis of maltose to trehalose by way of trehalose synthase (TS; EC:5.4.99.16; treS) (Streeter and Gomez 2006).

The four beta-rhizobia in Table 1 have genes for the same three pathways as Br. japonicum as well as multiple copies of them. For the first pathway, the B. tuberum genome contains one operon consisting of ots $A$ (TPS) and $o t s B$ (trehalose 6-phosphatase; EC:3.1.3.1.2; Fig. 3) as well as three additional copies of $o t s A$, two of which are paralogs (data not shown). A similar situation exists for the other three Burkholderia strains (Fig. 3), except that none of the ots $A$ genes have paralogs as seen in the B. tuberum genome.

Genes encoding MOTS and maltooligosyl trehalose hydrolase (EC: 3.2.1.14; treZ) were also found in the genomes of all four Burkholderia species. The gene neighborhoods are also very well conserved among the four Burkholderia species, and are similar in terms of gene organization to that of Rhizobium and Bradyrhizobium species, especially $B r$. japonicum USDA110 (Fig. 4). The gene sequences in the TS operon-glycogen branching enzyme ( $\lg X$; also known as tre $X$ ), and alpha-1,4-glucan:alpha-1,4-glucan 6-glycosyltransferase $(g \lg B)$-were also detected in both the beta- and alpha-rhizobial genomes.

Lastly, the genomes of the plant-associated Burkholderia strains, except for B. unamae, possess gene sequences encoding a neutral trehalase (EC:3.2.1.28; treF). This DNA sequence was not detected in the alpha-rhizobial genomes used in our analysis (data not shown).

Phosphate solubilization Available phosphate $(\mathrm{P})$ is generally in short supply in soils. Most of it is tied up in insoluble forms in either organic or inorganic complexes, which are unavailable to plants. Plant growth-promoting bacteria have the ability to hydrolyze organic $\mathrm{P}$ via a variety of mechanisms including: 1) nonspecific acid phosphatases (NSAPs), 2) phytases, and 3) phosphonatases and C-P lyases (Rodríguez et al. 2006). By contrast, inorganic phosphate is usually solubilized via the production of organic acids (Rodríguez and Fraga 1999).

Experimental analysis Inorganic P-solubilizing activity was observed for each of the four plant-associated Burkholderia species when PVK agar medium was supplemented with glucose as a carbon source, but $B$. tuberum was not as effective at solubilizing P compared to nonnodulating Burkholderia spp. (Fig. 5a). R. tropici CIAT899 solubilized $\mathrm{P}$ at a level similar to $B$. tuberum but statistically lower compared to B. unamae (Fig. 5a). Additionally, only PVA5 and SRMrh $20^{\mathrm{T}}$ were positive for solubilization of $\mathrm{P}$ when sucrose instead of glucose was added as a carbon source (Supplementary Information Fig. 2). Results from the QuantiChrom ${ }^{\mathrm{TM}}$ assay kit, which detects insoluble $\mathrm{P}$ confirm that the four Burkholderia spp. solubilize $\mathrm{P}$ after $24 \mathrm{~h}$ in liquid PVK medium (Fig. 5b). $R$. tropici CIAT899 was not tested in this assay. 
Fig. 3 Gene maps of the ots A/ots $B$ operon. The gene neighborhoods (shaded) of the four Burkholderia spp. are conserved with that of Bradyrhizobium japonicum USDA110

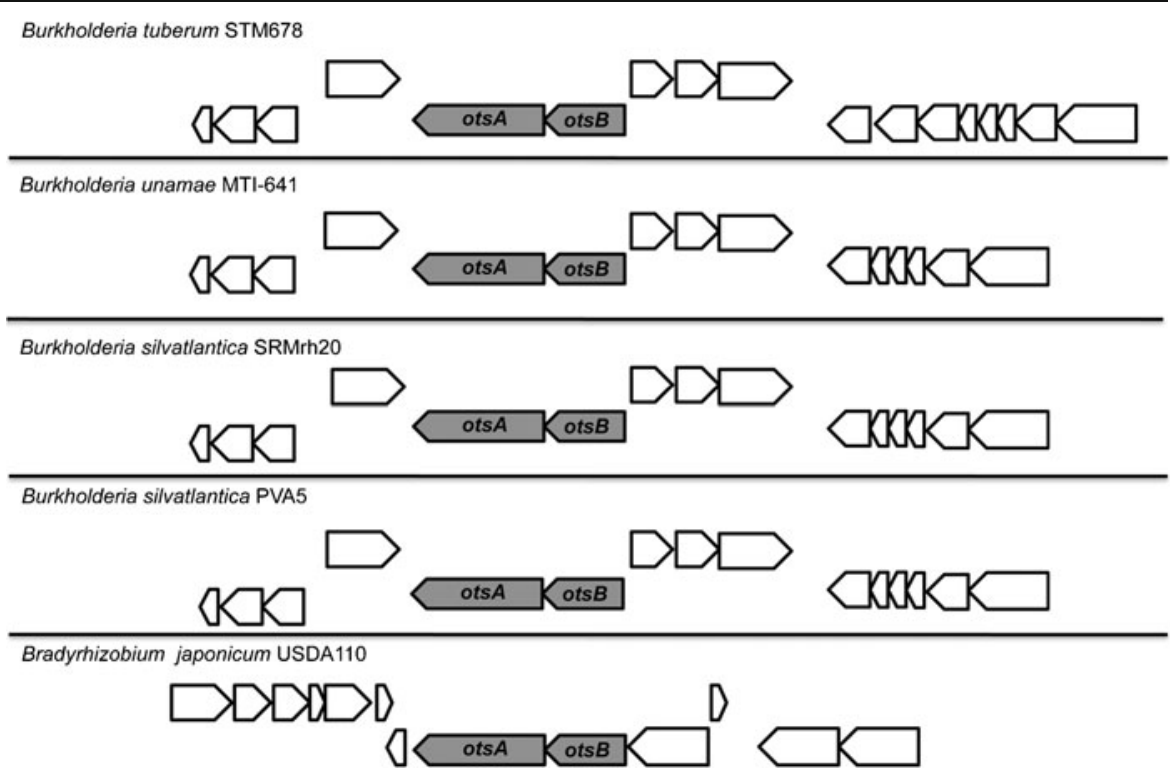

Because organic acid secretion is one of the principle ways that bacteria accomplish inorganic $\mathrm{P}$ solubilization (Rodríguez and Fraga 1999), we examined whether the ability of the four plant-associated Burkholderia strains to solubilize phosphate was correlated with an alteration in $\mathrm{pH}$. With the exception of B. tuberum $\mathrm{STM} 678^{\mathrm{T}}$, all the media in which the Burkholderia strains grew showed a $\mathrm{pH}$ drop close to 3.30 after $20 \mathrm{~h}$ of incubation regardless of the initial $\mathrm{pH}$ of the medium (Table 2). By $44 \mathrm{hpi}$, B. tuberum also elicited a significant $\mathrm{pH}$ drop in the medium. All four Burkholderia spp. solubilized
$\mathrm{CaHPO}_{4}$ to varying degrees on solid PVK plates by 72 hpi (Supplementary information Fig. 2).

When grown in PVK medium containing bromocresol purple at $\mathrm{pH} 7.55,6.53$, and 5.28 , the two B. silvatlantica strains demonstrated the greatest amount of phosphate solubilization at all the $\mathrm{pH}$ values tested whereas $B$. tuberum exhibited the least (Table 3). The sizes of the clearance zones and of the diameters of the color diffusion zones, related to the change from neutral to acidic $\mathrm{pH}$, are presented in Table 3. A correlation between the sizes of the diffusion zone and the zone of $\mathrm{P}$ solubilization is observed.
Fig. 4 MOTS and maltooligosyl trehalose hydrolase gene maps. The gene neighborhoods (shaded) of the four Burkholderia spp. are conserved with that of Bradyrhizobium japonicum USDA110

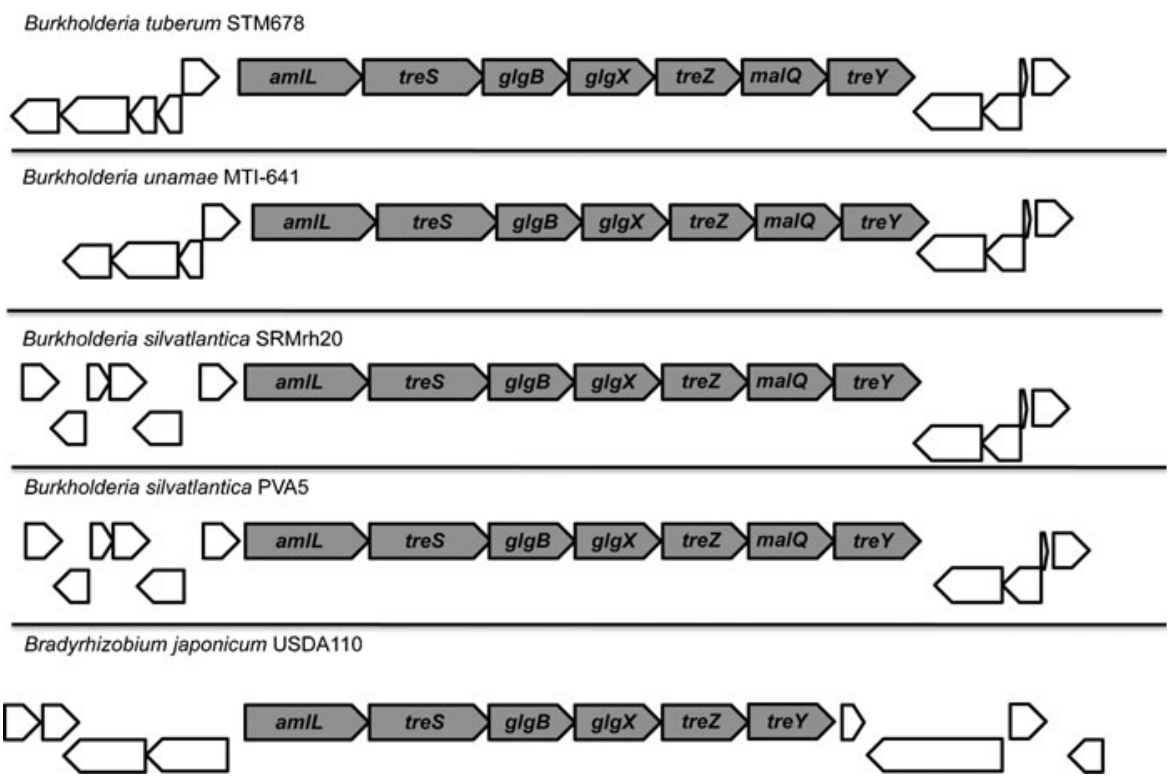




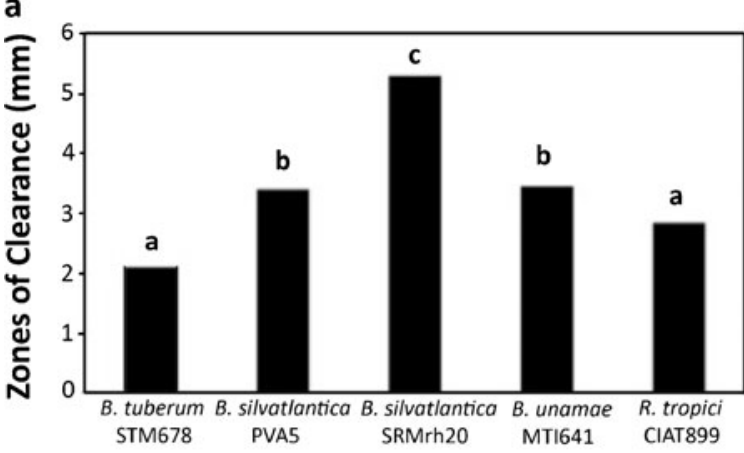

Strains Tested

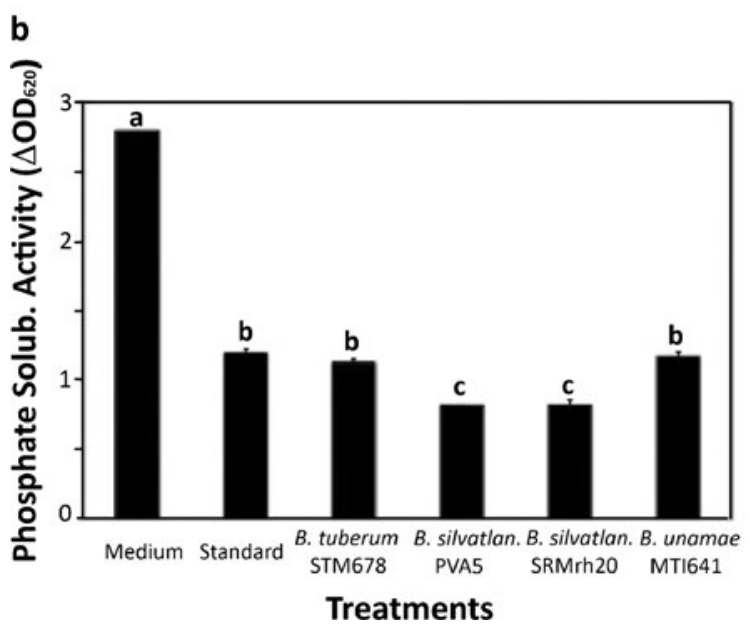

Fig. 5 Burkholderia species solubilize inorganic phosphate. a P-solubilizing activity for the four plant-associated Burkholderia species and $R$. tropici CIAT899 under the same conditions with glucose as a carbon source. Measurements indicate the zone of clearance (in $\mathrm{mm}$ ), calculated by measuring the surrounding halo after $48 \mathrm{~h}$ after equal OD readings of bacteria had been inoculated onto plates. b Quantification of P-solubilization activity in broth culture (the medium alone contains $36 \mu \mathrm{M} \mathrm{P}$ ) using the QuantiChrom ${ }^{\mathrm{TM}}$ assay kit, which detects insolubilized phosphate. B. tuberum and B. unamae solubilize $\mathrm{P}$ at levels close to that of the standard $(30 \mu \mathrm{M})$ after $24 \mathrm{~h}$, whereas B. silvatlantica PVA5 and SRMrh20 solubilize significantly more inorganic P. One-way ANOVA with Tukey's post hoc test was done for comparison of the means. Different letters represent values that differ significantly, $P<0.01$

Genome analysis Inorganic phosphate solubilization activity that is related to the production of organic acids (Rodríguez and Fraga 1999) is a property of several enzymes, particularly glucose dehydrogenase and the cofactor pyrroloquinoline quinone (PQQ). We searched for amino acid sequences of similar proteins in the Burkholderia genomes by querying with a Sinorhizobium meliloti sequence annotated as a probable glucose dehydrogenase (pyrroloquinoline-quinone) protein predicted to be involved in 6-phosphogluconate synthesis via gluconate (Fig. 6a). Each Burkholderia species has at least one coding sequence, and $B$. silvatlantica SRMrh $20^{\mathrm{T}}$ and PVA5 each have two copies (Table 4). Overall, the B. tuberum genome has the fewest number of gene sequences that could be involved in phosphate solubilization, which may explain the difference in activity of this strain on the PVK plates versus the other three.

Although we did not test the four Burkholderia strains for their ability to solubilize organic phosphate experimentally, we found gene sequences for NSAPs and similar enzymes, but not genes encoding phytases or phosphonatases and C-P lyases (Table 4). The genomes of all four Burkholderia spp. examined possess DNA sequences that encode a purple acid phosphatase-like protein (Table 4), which in B. cenocepacia has a $\mathrm{pH}$ optimum of 8.5 (Yeung et al. 2009). Purple acid phosphatase (PAP) generally breaks down phosphoric acid esters and phosphoric acid anhydrides, but the $B$. cenocepacia PAP was reported to be active towards phosphotyrosine, phosphoserine, and phosphoenolpyruvate (Yeung et al. 2009). The gene neighborhoods of the diazotrophic Burkholderia strains are almost identical while that of $B$. tuberum STM678 ${ }^{\mathrm{T}}$ differs.

A gene for a Burkholderia-type acid phosphatase (AcpA), generally used for the breakdown of organic $\mathrm{P}$ complexes, is also present in the genomes of all four of the species studied herein and in some alpharhizobia (Fig. 6b). Because B. tuberum exhibited lower phosphate solubilization compared to the non-nodulating strains, we also compared the genomes of two of the sequenced nodulating strains with the genomes of $B$. unamae, $B$. silvatlantica PVA5, and B. silvatlantica SRMrh20 ${ }^{\mathrm{T}}$. The acpA gene neighborhoods of both $B$. tuberum and $B$. phymatum STM $815^{\mathrm{T}}$ differed not only from each other, but also from the comparable neighborhoods in B. unamae and in the two B. silvatlantica species. Interestingly, for the genomes of two sequenced $B$. mimosarum strains, the acpA neighborhoods matched those of the non-nodulating strains, suggesting that the arrangement of genes putatively involved in organic phosphate solubilization is not correlated with nodulation ability per se. Also, two 
Table 2 pH of PVK medium 20 and 44 h post-inoculation (hpi)

\begin{tabular}{|c|c|c|c|c|c|c|}
\hline \multirow[t]{2}{*}{ Strain } & \multicolumn{2}{|l|}{$\mathrm{pH} 7.55^{\mathrm{a}}$} & \multicolumn{2}{|l|}{$\mathrm{pH} 6.53^{\mathrm{a}}$} & \multicolumn{2}{|l|}{$\mathrm{pH} 5.28^{\mathrm{a}}$} \\
\hline & 20 hpi & 44 hpi & 20 hpi & 44 hpi & 20 hpi & 44 hpi \\
\hline Uninoculated $^{\mathrm{b}}$ & 6.01 & 6.21 & 5.38 & 5.54 & 5.03 & 4.86 \\
\hline B. tuberum STM678 ${ }^{\mathrm{T}}$ & $7.35 \pm 0.04$ & $3.93 \pm 0.02$ & $6.45 \pm 0.03$ & $3.71 \pm 0.16$ & $4.33 \pm 0.14$ & $3.65 \pm 0.08$ \\
\hline B. unamae MTI- $641^{\mathrm{T}}$ & $3.33 \pm 0.05$ & $3.17 \pm 0.01$ & $3.38 \pm 0.06$ & $3.09 \pm 0.03$ & $3.28 \pm 0.09$ & $3.14 \pm 0.02$ \\
\hline B. silvatlantica PVA5 & $3.41 \pm 0.04$ & $3.18 \pm 0.01$ & $3.28 \pm 0.05$ & $3.20 \pm 0.12$ & $3.27 \pm 0.06$ & $3.07 \pm 0.01$ \\
\hline B. silvatlantica $\mathrm{SRMrh} 20^{\mathrm{T}}$ & $3.35 \pm 0.01$ & $3.16 \pm 0.03$ & $3.32 \pm 0.02$ & $3.02 \pm 0.02$ & $3.27 \pm 0.07$ & $3.07 \pm 0.01$ \\
\hline
\end{tabular}

${ }^{\text {a }}$ Original $\mathrm{pH}$ of medium and subsequent measurements in triplicate are displayed

${ }^{\mathrm{b}}$ The uninoculated control was incubated under the same conditions as the inoculated cultures. The values indicate only a single reading recorded per time point

AcpA-encoding genes were detected in the genomes of the non-nodulating strains, with no orthologs in B. tuberum STM678 ${ }^{\mathrm{T}}$, which had only one acpA (Table 4).

\section{Siderophore secretion}

Alpha-rhizobia are known to bind iron through the secretion of siderophores, and several plant-associated Burkholderia species have already been shown to be capable of this activity (Caballero-Mellado et al. 2007; Suárez-Moreno et al. 2012; Weisskofp et al. 2011). Similar to phosphate solubilization, these activities are beneficial because they support the growth and development of plants, especially in marginalized soils, by making unattainable mineral nutrients available.
Experimental analysis Iron acquisition via siderophore secretion was detected using the CAS overlay agar plate assay on all four Burkholderia species. The presence of yellow/orange halos around the bacterial colonies indicates the presence of iron-binding siderophores. $B$. tuberum consistently formed the smallest halos whereas B. unamae established the largest (Supplementary information Fig. 3). To determine whether a connection could be made between halo size and genes involved in siderophore production, we analyzed the sequenced genomes of the four Burkholderia species.

Genome analysis Genome analysis revealed that several genes described as siderophore receptors, siderophore transport system components, and siderophoreinteracting proteins are found in the genomes of the four plant-associated species. Interestingly, the B. unamae

Table 3 Zones of clearance and color change on PVK agar plates containing bromocresol purple 72 hpi

\begin{tabular}{|c|c|c|c|c|c|c|}
\hline \multirow[t]{2}{*}{ Strain } & \multicolumn{2}{|l|}{$\mathrm{pH} 7.55^{\mathrm{a}}$} & \multicolumn{2}{|l|}{$\mathrm{pH} 6.53^{\mathrm{a}}$} & \multicolumn{2}{|l|}{$\mathrm{pH} 5.28^{\mathrm{a}}$} \\
\hline & $\begin{array}{l}\text { Halo:colony } \\
\text { average }^{b}\end{array}$ & $\begin{array}{l}\text { Diameter of color } \\
\text { diffusion }^{\mathrm{c}}(\mathrm{mm})\end{array}$ & $\begin{array}{l}\text { Halo:colony } \\
\text { average }^{\mathrm{b}}\end{array}$ & $\begin{array}{l}\text { Diameter of color } \\
\text { diffusion }^{\mathrm{c}}(\mathrm{mm})\end{array}$ & $\begin{array}{l}\text { Halo:colony } \\
\text { average }^{b}\end{array}$ & $\begin{array}{l}\text { Diameter of color } \\
\text { diffusion }^{\mathrm{c}}(\mathrm{mm})\end{array}$ \\
\hline B.tuberum STM678 ${ }^{\mathrm{T}}$ & 1.33 & 11 & 1.29 & 11 & 1.43 & n.r. \\
\hline B.unamae MTI- $641^{\mathrm{T}}$ & 1.53 & 26 & 1.67 & 21 & 1.63 & n.r. \\
\hline B. silvatlantica PVA5 & 2.00 & 31 & 1.79 & 28 & 1.81 & n.r. \\
\hline B. silvatlantica $\mathrm{SRMrh} 20^{\mathrm{T}}$ & 1.92 & 29 & 1.80 & 33 & 1.69 & n.r. \\
\hline
\end{tabular}

${ }^{\text {a }}$ Original $\mathrm{pH}$ of medium and subsequent measurements in triplicate are displayed

${ }^{b}$ The ratio of the zone of clearance to the colony size is reported. A value $>1$ indicates solubilization of $\mathrm{CaHPO}_{4}$

${ }^{\mathrm{c}}$ The average diameter of the diffusion of color is shown. A change in color from purple to yellow indicates a decrease in the $\mathrm{pH}$ of the medium

n.r., not recorded. Measurements for pH5.28 are not shown due to a complete diffusion of yellow throughout the plates 
Fig. 6 P solubilization gene maps. a The PQQ gene neighborhoods of four Burkholderia spp. compared to that of S. meliloti. b The orientation and surrounding neighborhoods for the acp $A$ gene in the nodulating species B. tuberum and B. phymatum are different from the non-nodulating Burkholderia species. However, the nodulating $B$. mimosarum strain gene neighborhoods are identical to those of $B$. unamae and the two B. silvatlantica strains a

Burkholderia tuberum STM678

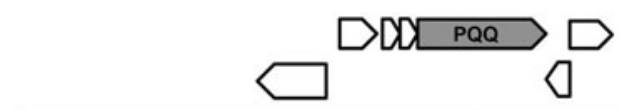

Burkholderia unamae MTI-641

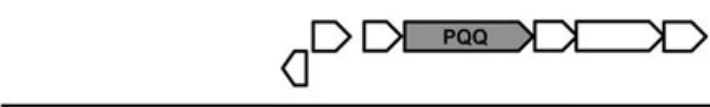

Burkholderia silvatlantica SRMrh20

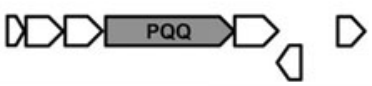

Burkholderia silvatlantica PVA5

$D D \square \longdiv { P Q Q } \times \square \square$

Sinorhizobium meliloti 1021

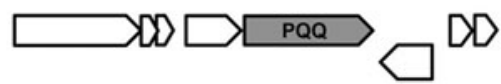

b

Burkholderia tuberum STM678

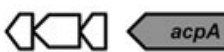

WD

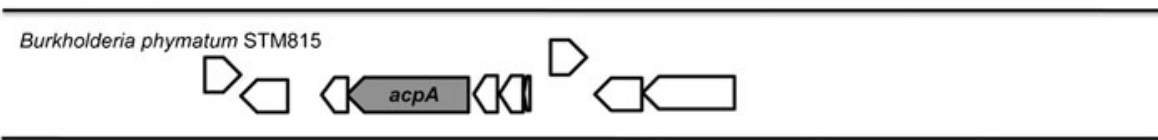

Burkholderia silvatlantica SRMrh20

acpa $K \square \square \curvearrowleft \square \square$

Burkholderia silvatlantica PVA5

асрА $К \square \square \square \square$

Burkholderia unamae MTL641

acpa $K \square \square \subset \subset \square$

Burkholderia mimosarum STM3621

acpA $\square \square \square \square$

Burkholderia mimosarum LMG 23256

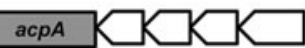

genome contains 16 genes potentially encoding TonBdependent siderophore receptors whereas each $B$. silvatlantica strain has four (Table 5). B. tuberum has three genes annotated as TonB siderophore receptors (Table 5), one of which may be non-functional (see below). Some of the TonB-dependent siderophore receptors listed in Table 5 are in an operon (see consecutive gene numbers and similar superscripted letters) with 1) an ABC-type cobalamin $/ \mathrm{Fe}^{3+}$-siderophore transport system, 2) an
ATPase component (EC:3.6.3.34), 3) an ABC-type cobalamin $/ \mathrm{Fe}^{3+}$-siderophore transport system, permease component, and 4) an $\mathrm{ABC}$-type $\mathrm{Fe}^{3+}$-hydroxamate transport system, periplasmic component genes (Table 5). In addition, several ABC-type $\mathrm{Fe}^{+3}$-siderophore transport system, and ATPase and permease component genes were found in the genomes, but were not associated with siderophore protein-encoding genes. Genes encoding a potential periplasmic component of a 
Table 4 List of locus tags for gene sequences encoding proteins that are likely to be involved in phosphate solubilization

\begin{tabular}{|c|c|c|c|c|}
\hline \multirow[t]{2}{*}{ Gene function and name } & \multicolumn{4}{|l|}{ Locus tag } \\
\hline & B. tuberum STM678 & B. unamae MTI641 ${ }^{\mathrm{T}}$ & B. silvatlantica PVA5 & B. silvatlantica $\mathrm{SRMrh} 20^{\mathrm{T}}$ \\
\hline \multicolumn{5}{|c|}{ Inorganic Phosphate Solubilization } \\
\hline \multicolumn{5}{|c|}{ Membrane-bound PQQ-dependent dehydrogenase glucose/quinate/shikimate family } \\
\hline & GCWU001488_06170 & GCWU001489_05348 & GCWU001490_06856 & GCWU001491_04527 \\
\hline & - & - & GCWU001490_04976 & GCWU001491_06776 \\
\hline \multicolumn{5}{|c|}{ Organic Phosphate Solubilization } \\
\hline \multicolumn{5}{|c|}{ Putative purple alkaline phosphatase } \\
\hline & GCWU001488_04845 & GCWU001489_02415 & GCWU001490_05774 & GCWU001491_07093 \\
\hline \multicolumn{5}{|l|}{ Acid phosphatase AcpA } \\
\hline & GCWU001488_05111 & GCWU001489_03077 & GCWU001490_05252 & GCWU001491_06457 \\
\hline & - & GCWU001489_01734 & GCWU001490_01837 & GCWU001491_02862 \\
\hline
\end{tabular}

hydroxamate transport system were also present (Table 5). Such a transport system had been detected earlier in B. unamae (Caballero-Mellado et al. 2007).

The first of three $B$. tuberum siderophore receptors, GCWU001488_01779, is adjacent to a gene putatively encoding a protein involved in ABC-type cobalamin/ $\mathrm{Fe}^{3+}$-siderophore transport (GCWU001488_01778) (Table 5). GCWU001488_01779 is orthologous and 69-70\% identical to genes encoding putative siderophore receptors in $B$. glumae (bglu_2g14800) and B. gladioli (bgla_2g10490). The immediate gene neighborhoods of $B$. glumae and $B$. gladioli are almost identical to that of B. tuberum, but a putative transposon adjacent to GCWU001488_01778 suggests that this insertion in the B. tuberum operon could result in the truncation of a putative ABC-type $\mathrm{Fe}^{3+}$-hydroxamate transport system, periplasmic component (GCWU001488_01777). On the other hand, homologs to either the ATPase or periplasmic component genes observed in B. unamae and B. tuberum were not detected in the two strains of nitrogen-fixing $B$. silvatlantica examined in this study (Table 5).

The second putative TonB siderophore receptor (GCWU001488_04562) in B. tuberum is orthologous to a gene of the same name in several Burkholderia species and also in B. unamae (64\% identity; GCWU001489_04829), but not to genes in either of the two B. silvatlantica strains (Table 5). Like the $B$. unamae siderophore receptor, this gene is not adjacent to other iron transporter-encoding genes. The $B$. tuberum siderophore receptor is predicted to be in COG1629 (Fe receptor), whereas the $B$. unamae ortholog is annotated as a protein in COG4774 (catecholate receptor). However, so far no experimental evidence exists for the latter type of receptor in B. unamae.

The third gene annotated as a B. tuberum TonB siderophore receptor (GCWU001488_05039) is orthologous to a comparable sequence in a number of Burkholderia species, including the ones studied here (from 74 to $76.3 \%$ sequence identity), and also to genes in the B. xenovorans $(84.2 \%)$ and B. phytofirmans $(84 \%)$ genomes. A gene that putatively encodes 2OG-Fe(II) oxygenase (GCWU001488_05038) is adjacent to the TonB siderophore receptor as well as to its ortholog siderophore receptors in the other three nitrogen-fixing Burkholderia spp. (Table 5).

In B. unamae, a gene annotated as lysine/ornithine Nmonooxygenase (GCWU001489_07200) shows 59$60 \%$ identity to a Bordetella pertussis gene encoding a biosynthesis enzyme (alcA) for alcaligin, a dihydroxamate siderophore. Although similarities existed between the $B$. unamae sequence and a $B$. tuberum gene, only $31 \%$ identity on the protein level was observed between them. Moreover, no other alc-like genes were found in B. tuberum or in the two B. silvatlantica strains. Adjacent to the $B$. unamae alcA-like gene lies a sequence encoding an arabinose efflux protein and adjacent to that is an alcB-like gene with $70.9 \%$ identity to a protein annotated in Burkholderia sp. CCGE1002 as a siderophore biosynthesis protein (YP_003610151.1), and with ca. $58 \%$ identity to an alcaligin biosynthesis protein in two strains of Achromobacter xylosoxidans (EGP43454.1, YP_003979104.1), and $55 \%$ identity to an alcB gene product in Bordetella pertussis Tohama I 


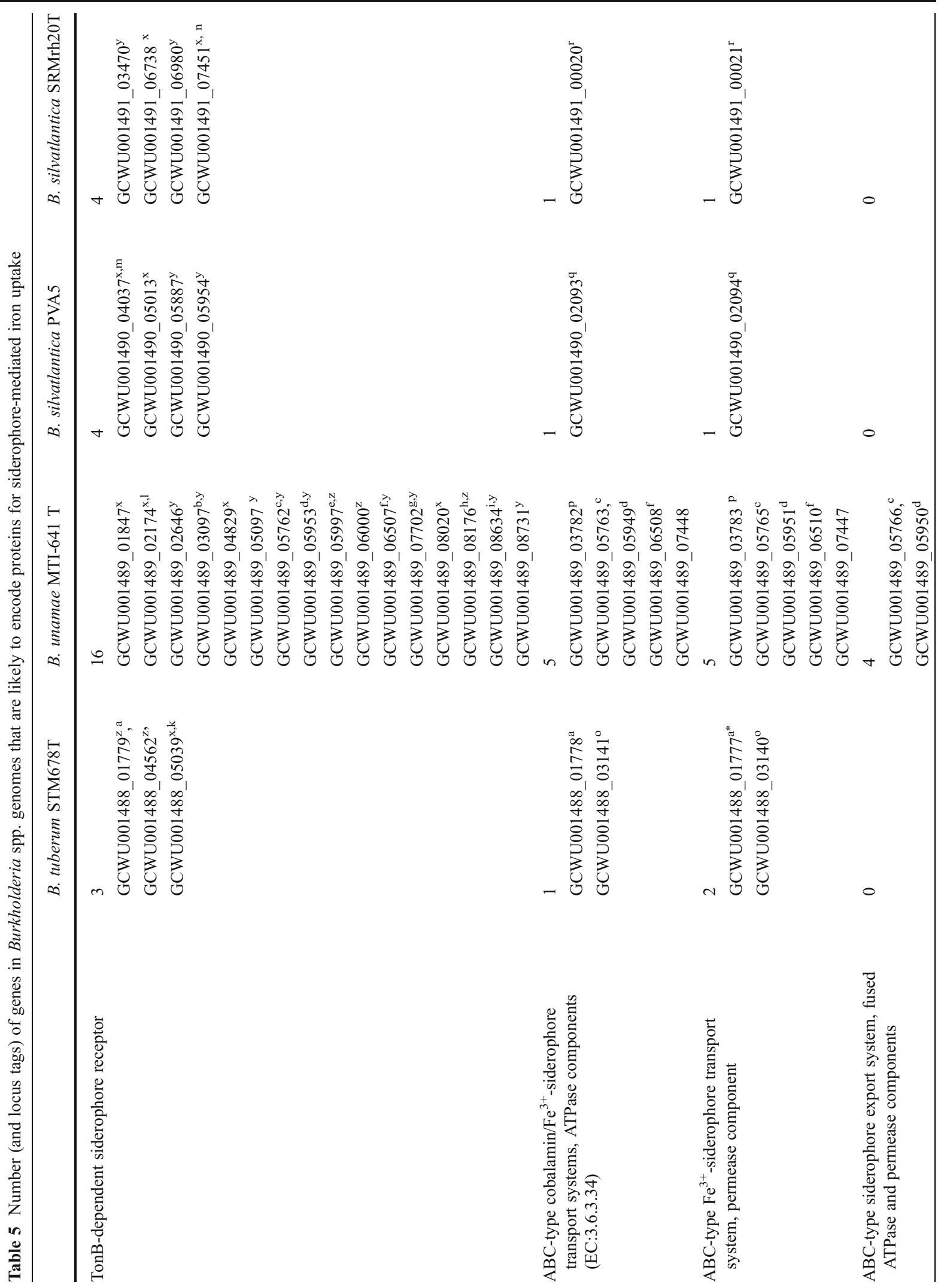




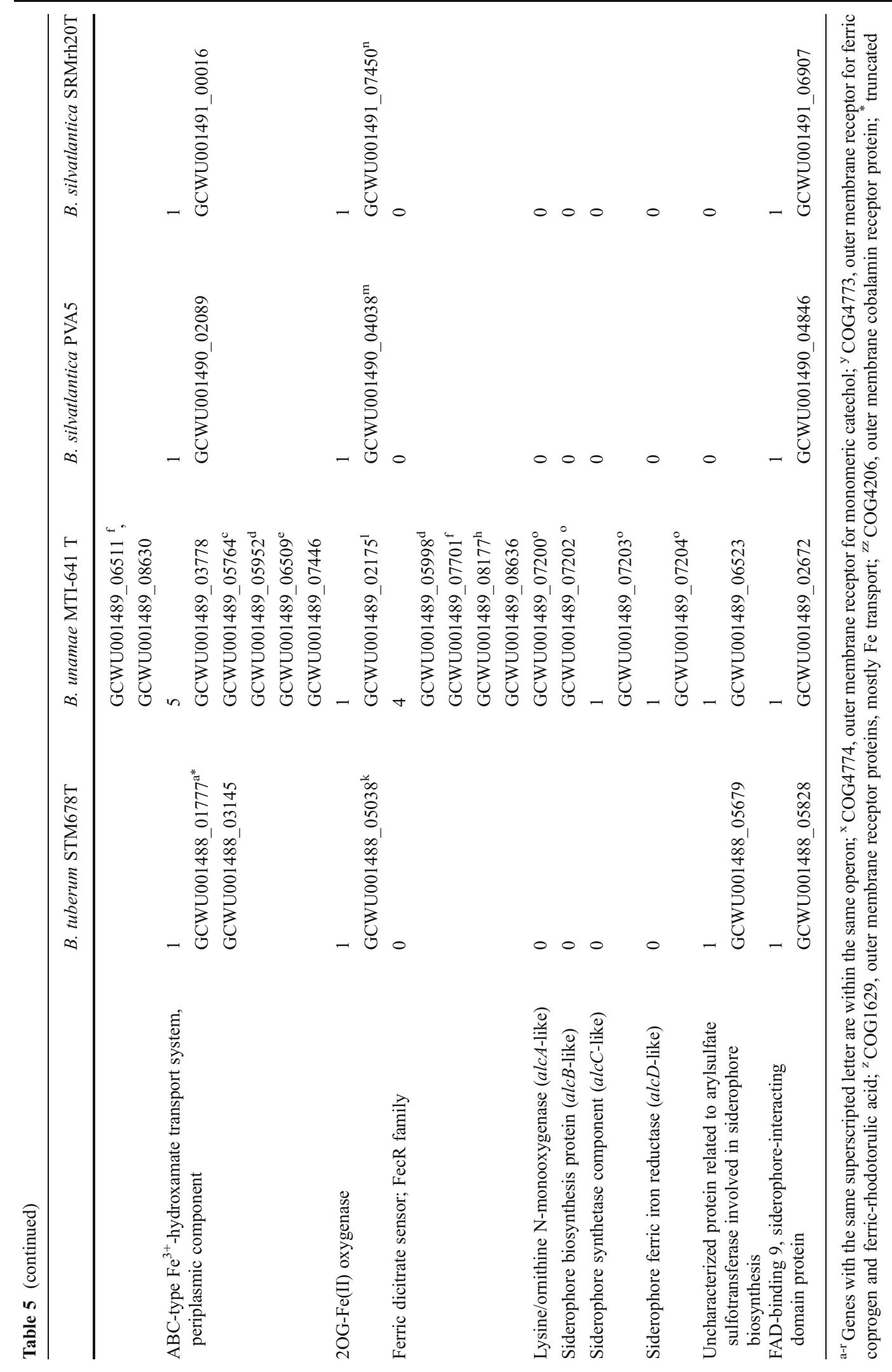


(NP_881084.1). Immediately adjacent to the alcB-like sequence is a gene coding for a siderophore synthetase component (GCWU001489_07205), with $63 \%$ amino acid sequence identity to alcC in A. xylosoxidans (EFV887439.1), $61 \%$ identity to the alcC gene in the various Bordetella species (NP_881085.1, CAA3891.1, and NP_885606.1), and $59 \%$ to alcC in Pseudomonas stutzeri (YP_004716031.1). Lastly, a siderophore ferric iron reductase for alcaligin synthesis (alcD), (GCWU001489_07204), which is annotated in Burkholderia spp. CCGE1002 as a hypothetical protein (YP_003610153.1; $61 \%$ identity), is found in B. unamae (Table 5, Fig. 7). The gene call was made on $42 \%$ identity to the alcD gene in Bordetella pertussis, $B$. bronchiseptica, and B. parapertussis (NP_881086.1, CAA3891.1, and NP_885607.1). These and other proteins, such as arylsulfate sulfotransferase (Mathew et al. 2001), may be involved in siderophore synthesis and are listed in Table 5.

\section{Discussion}

B. tuberum STM678 ${ }^{\mathrm{T}}$ was originally identified as a Bradyrhizobium species (Muofhe and Dakora 1998) because of its slow growth on plates upon isolation from nodules, and was named Bradyrhizobium aspalati because it was isolated from Aspalathus carnosa (see Elliott et al. 2007a and Gyaneshwar et al. 2011). However, it induced effective nodulation on siratro roots (Elliott et al. 2007a), although Moulin et al. (2001) had reported the phenotype as Fix.

We wanted to obtain a deeper understanding of the conditions that modulated whether $\mathrm{Fix}^{+}$or $\mathrm{Fix}^{-}$nodules are produced on siratro so that effective nodulation could be obtained on a reliable and predictable basis. We found that a porous soil mixture with infrequent watering resulted in B. tuberum STM678 ${ }^{\mathrm{T}}$-induced $\mathrm{Fix}^{+}$nodules on siratro. However, when $R$. tropici CIAT899, a strain that is also tolerant of acid soils and thus expected to be a good reference strain, was used as an inoculum under the conditions tested, Fix ${ }^{-}$nodules developed on siratro. In contrast, cowpea plants included in the same dishpans as the siratro plants nodulated and fixed nitrogen (data not shown).

An analysis of the literature concerning $R$. tropici CIAT899 does not provide definitive answers. Hernandez-Lucas et al. (1995) reported that this strain induced two types of nodules on siratro - those that had leghemoglobin and those that lacked it and contained senescent, darkened cells. It was not clear from this report whether the nodules that contained leghemoglobin were actually fixing nitrogen. Collavino et al. (2005) tested the guaA mutant of $R$. tropici CIAT899 on siratro and found that it elicited ineffective nodules, but a mature, wild-type, $\mathrm{Fix}^{+}$nodule was not illustrated in this study. However, unpublished data from one of the authors (O.M. Aquilar, pers. com.) indicates that Fix ${ }^{+}$ nodules were elicited by this strain. The difference in phenotypes described in our results and the previously published work cannot be explained at this time, in part due to the differences in growth conditions. Changes in temperature and water availability could make a significant difference in nodule outcome. Moreover, it is also possible that $R$. tropici CIAT899 only marginally nodulates siratro as suggested by the results of HernandezLucas et al. (1995).

$R$. tropici CIAT899 was originally described as $R$. leguminosarum bv. phaseoli and nodulates bean and Leucaena sp. effectively (Martínez-Romero et al. 1991; Riccillo et al. 2000) at high temperatures although acetylene reduction activity was reduced in bean (Michiels et al. 1994). This strain's ability to nodulate a diverse number of legumes and under different environmental conditions is most likely conditioned by the large variety of Nod factors produced by CIAT899. $R$. tropici Nod factors have typical backbones consisting of four or five $\beta-1,4$ linked $N$-acetylglucosamine residues, but the number and types of substitutions on the lipo-chitooligosaccharide varies significantly depending on the environmental conditions. For example, under low $\mathrm{pH}, 59$ Nod factors were produced whereas 29 different structures were synthesized at neutral pH (Móron et al. 2005). Additional and different Nod factors were also detected following salt stress (Estévez et al. 2009). In contrast, Boone et al. (1999) identified only two major Nod factors of B. tuberum STM678 ${ }^{\mathrm{T}}$, then known as Bradyrhizobium aspalati. These factors have either a tetrameric or pentameric $\mathrm{N}$-acetylglucosamine backbone, but instead of having substitutions on the reducing end as observed in alpha-rhizobia, these Nod factors are substituted only on the non-reducing end of the molecule. In any case, whether or not different Nod factors arise following abiotic stress has not been tested for the beta-rhizobia. Other than for B. tuberum STM678 ${ }^{\mathrm{T}}$, no other Nod factor structures have been determined for the nodulating Burkholderia species. 
Burkholderia unamae MTI-641

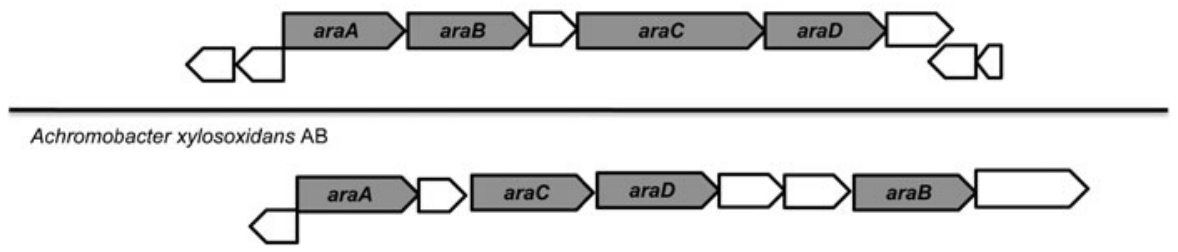

Fig. 7 Genes potentially encoding a hydroxamate siderophore. Of the four Burkholderia genomes surveyed, only the genome of $B$. unamae has genes coding for alcaligin, a hydroxamate

B. tuberum STM678 ${ }^{\mathrm{T}}$-inoculated siratro plants remained green and developed pink, Fix $^{+}$nodules even under desiccating conditions, which differs from Rhizobium strains in general (Michiels et al. 1994). Both $B$. phymatum STM $815^{\mathrm{T}}$ and $B$. tuberum $\mathrm{STM} 678^{\mathrm{T}}$ have been shown to fix nitrogen ex planta, although not to the levels of $B$. vietnamiensis TVV75 (Elliott et al. 2007b). This ability may be the reason that $B$. tuberum is able to fix nitrogen symbiotically under stressful conditions.

Besides nitrogen fixation, rhizosphere bacteria enhance plant growth in a number of diverse ways, among them protecting plants from abiotic stress, and improving phosphate or iron nutrition. Various environmental stresses such as reduced water availability and increased temperature also significantly influence nodulation effectiveness. We found that siratro nodulation was improved by higher temperatures and was effective even under conditions of reduced water availability. In contrast, $R$. tropici elicited Fix ${ }^{-}$ nodules on siratro when grown under these conditions. Trehalose is synthesized by a broad range of organisms including plants, bacteria, archaea, and insects (Iturriaga et al. 2009) as a means of dealing with either desiccation or thermal stress. The beta-rhizobial genomes, except for B. unamae, possessed an additional trehalose biosynthetic pathway compared to alpha-rhizobial genomes. A partial ots $A$ gene sequence (AFH35528.1) from $R$. tropici exhibited only $46 \%$ amino acid sequence identity to the ots $A$ sequence in the Burkholderia spp. However, we cannot make a more direct comparison with $R$. tropici because only a draft genome analysis of this species has been published (Pinto et al. 2009). Information about the number of trehalose biosynthetic pathways in this species is thus not available at this time.

Of the four Burkholderia spp. investigated, B. silvatlantica PVA5 and SRMrh $20^{\mathrm{T}}$ exhibited the largest siderophore. The B. unamae gene neighborhood is compared to the orthologous operon in Achromobacter xylosoxidans AB

amount of phosphate solubilization activity and also possessed the most gene sequences potentially involved in inorganic and organic phosphate breakdown based on analysis of the sequenced genomes. The drop in $\mathrm{pH}$ upon mineralizing $\mathrm{CaHPO}_{4}$ in the $\mathrm{PVK}$ plates strongly suggests that production of glucuronic or another organic acid may be involved in inorganic P solubilization, and that the plant-associated Burkholderia species are likely inhabitants of soils that are low in soluble phosphate. Burkholderia species have been described previously as having a preference for acidic soils (Garau et al. 2009; Dos Reis et al. 2010). A recent study of Burkholderia in French Guinea suggests that betarhizobia exclusive of Cupriavidus taiwanensis, which prefers alkaline soils, were dominant in low $\mathrm{pH}$ soils (Mishra et al. 2012). In a similar vein, Estrada-de los Santos et al. (2011) isolated only a few Burkholderia species associated with agricultural plants growing in the alkaline soils of northern Mexico in contrast to Cupriavidus species, which were isolated more frequently. Isolation of Burkholderia species from alkaline soils in Australia has been reported (see Gyaneshwar et al. 2011), but more studies are needed.

Siderophores, which make iron available, are important for host colonization by bacteria (Mietzner and Morse 1994). Of the four nitrogen-fixing Burkholderia strains, B. unamae produced the largest halos using the CAS-overlay medium whereas $B$. tuberum exhibited the least activity. Genome analysis showed that $B$. unamae contains more gene sequences for TonB-dependent associated siderophore receptors and their associated genes than did the other three species, which may explain the increased activity. Although B. unamae does not nodulate plants, it was originally isolated from the roots of maize and sugarcane (Table 1) and thus can be classified as a plant-associated diazotroph. The genome of B. tuberum, which contains nod genes, has three siderophore receptors and the genomes of the other 
two $B$. silvatlantica strains each have four. Both $B$. silvatlantica SRMrh $20^{\mathrm{T}}$ (Perin et al. 2006) and PVA5 (de Faria et al. 1999) were isolated from the interstices of plant roots and fix nitrogen, but are not capable of nodulating roots.

Earlier reports indicated that siratro's small size, ability to grow under controlled conditions, prolonged seed viability, and promiscuity with respect to nodulation (Vincent 1970; Pueppke and Broughton 1999) supported its usefulness as a plant for studying responses to rhizobia. Recently, Lima et al. (2009) and Mishra et al. (2012) endorsed its value as a trap plant for both alpha- and beta-rhizobia. Based on our studies, we believe that this small-seeded legume is also an excellent model system for analyzing plant responses to $B$. tuberum inoculation under a wide range of environmental conditions.

Acknowledgments This research was supported in part by a grant (IOB-0537497) from the National Science Foundation (USA) to GW and AMH and a Shanbrom Family Foundation grant to AMH. A University of California Office of The President, President's Postdoctoral Fellowship, supported AA. We thank the National Germplasm Collection of the USDA-ARS for seeds of various cowpea varieties that were tested and the Joint Genome Institute/Department of Energy for the annotation platform. LMU's Seaver College of Science and Engineering M.A.N.E. laboratory is thanked for the use of the confocal microscope.

Liamara Perin and Veronica M. Reis of EMBRAPA are acknowledged for their previous research on Burkholderia species and for providing helpful information regarding $B$. silvatlantica SRMrh $20^{\mathrm{T}}$. J. Peter Young is thanked for providing the B. tuberum/gfp strain. Members of the Hirsch laboratory, especially Drs. Drora Kaplan and Nisha Tak are thanked for reviewing the manuscript.

This paper is dedicated to the memory of Jesus CabelleroMellado, one of the pioneers in the study of the plant-associated Burkholderia species.

\section{References}

Ahmed B, Quilt P (1980) Effect of soil moisture stress on yield, nodulation and nitrogenase activity of Macroptilium atropurpureum cv. Siratro and Desmodium intortum cv. Greenleaf. Plant Soil 57:187-194

Andrews SC, Robinson AK, Rodriguez-Quiñones F (2003) Bacterial iron homeostasis. FEMS Microbiol Rev 27:215237

Boone CM, Olsthoorn MMM, Dakora FD, Spaink HP, ThomasOates JE (1999) Structural characterization of lipooligosaccharides isolated from Bradyrhizobium aspalati, microsymbionts of commercially important South African legumes. Carbohyd Res 317:155-163
Brigham RD, Hoover MM (1956) A scarifying cup for small lots of legume seed. Agron J 48:531-532

Caballero-Mellado J, Martínez-Aquilar L, Paredes-Valdez G, Estrada-de los Santos P (2004) Burkholderia unamae sp. nov., an $\mathrm{N}_{2}$-fixing rhizospheric and endophytic species. Int J System Evol Microbiol 54:1165-1172

Caballero-Mellado J, Onofre-Lemus J, Estrada-de Los Santos P, Martínez-Aguilar L (2007) The tomato rhizosphere, an environment rich in nitrogen-fixing Burkholderia species with capabilities of interest for agriculture and bioremediation. Appl Environ Microbiol 73:5308-5319

Castro-González R, Martínez-Aquilar L, Ramírez-Trujillo A, Estrada-de los Santos P, Caballero-Mellado J (2011) High diversity of culturable Burkholderia species associated with sugarcane. Plant Soil. doi:10.1007/s11104-01107680-0

Chen W-M, Moulin L, Bontemps C, Vandamme P, Béna G, Boivin-Masson C (2003) Legume symbiotic nitrogen by $\beta$-proteobacteria is widespread in nature. $\mathrm{J}$ Bacteriol 185:7266-7272

Chen W-M, James EK, Coenye T, Chou J-H, Barrios E, de Faria SM, Elliott GN, Sheu SY, Sprent JI, Vandamme P (2006) Burkholderia mimosarum sp. nov., isolated from root nodules of Mimosa spp. from Taiwan and South America. Int J System Evol Microbiol 56:1847-1851

Chen W-M, de Faria SM, James EK, Elliott GN, Lin KY, Chou J-H, Sheu SY, Cnockaert M, Sprent JI, Vandamme P (2007) Burkholderia nodosa sp. nov., isolated from root nodules of the woody Brazilian legumes Mimosa bimucronata and Mimosa scabrella. Int J System Evol Microbiol 57:1055-1059

Cheng H-P, Walker GC (1998) Succinoglycan is required for initiation and elongation of infection threads during nodulation of alfalfa by Rhizobium meliloti. J Bacteriol 180:5183-5191

Collavino M, Riccillo PM, Grasso DH, Crespi M, Aguilar OM (2005) GuaB activity is required in Rhizobium tropici during the early stages of nodulation of determinate nodules but is dispensable for the Sinorhizobium meliloti-alfalfa symbiotic interaction. Mol Plant-Microbe Inter 18:742-750

de Faria SM, de Lima HC, Olivares FL, Melo RB, Xavier RP (1999) Nodulação em espécies florestais, especificidade hospedeira e implicações na sistemática de leguminosae. In: Siqueira JO, Moreira FMS, Lopes AS, Guiherme LRG, Faquin V, Furtinia Neto AE, Carvalho JG (eds) Soil Fertility, Soil Biology, and Plant Nutrition Interrelationships. Soc Brasil Ciên Univ Fed Lavras. pp. 667-686

Dos Reis FB Jr, Simon MF, Gross E, Boddey RM, Elliott GN, Neto NE, Loureiro MF, de Queiroz LP, Scotti MR, Chen W-M, Norén A, Rubio MC, de Faria SM, Bontemps C, Goi SR, Young JP, Sprent JI, James EK (2010) Nodulation and nitrogen fixation by Mimosa spp. in the Cerrado and Caatinga biomes of Brazil. New Phytol 186:934-946

Elliott GN, Chen W-M, Bontemps C, Chou J-H, Young JPW, Sprent JI, James EK (2007a) Nodulation of Cyclopia spp. (Leguminosae, Papilionoideae) by Burkholderia tuberum. Ann Bot 100:1403-1411

Elliott GN, Chen W-M, Chou J-H, Wang H-C, Sheu SY, Perin L, Reis VM, Moulin L, Simon MF, Bontemps C, Sutherland JM, Bessi R, de Faria SM, Trinick MJ, 
Prescott AR, Sprent JI, James EK (2007b) Burkholderia phymatum is a highly effective nitrogen-fixing symbiont of Mimosa spp. and fixes nitrogen ex planta. New Phytol 173:168-180

Estévez J, Soria Díaz ME, Fernández de Córdoba F, Móron B, Manyan H, Gil A, Thomas-Oates J, van Brussel AAN, Dardanelli MS, Sousa C, Megías M (2009) Different and new Nod factors produced by Rhizobium tropici CIAT899 following $\mathrm{Na}^{+}$stress. FEMS Microbiol Lett 293:220-231

Estrada-de los Santos P, Vacaseydel-Aceves NB, MartínezAquilar L, Cruz-Hernández MA, Mendoza-Herrera A, Caballero-Mellado J (2011) Cupriavidus and Burkholderia species associated with agricultural plants that grow in alkaline soils. J Microbiol 49:867-876

Fujishige NA, Lum MR, De Hoff PL, Whitelegge JP, Faull KF, Hirsch AM (2008) Rhizobium common nod genes are required for biofilm formation Mol. Microbiology 67:504-515

Garau G, Yates RJ, Deiana P, Howieson JG (2009) Novel strains of nodulating Burkholderia have a role in nitrogen fixation with papilionoid herbaceous legumes adapted to acid, infertile soils. Soil Biol Biochem 41:125-134

Graham PH, Viteri SE, Mackie F, Vargas AAT, Palacios A (1982) Variation in acid soil tolerance among strains of Rhizobium phaseoli. Field Crops Res 5:121-128

Graham PH, Draeger KJ, Ferrey ML, Conroy MJ, Hammer BE, Martínez E, Arons SR, Quinto C (1994) Acid pH tolerance in strains of Rhizobium and Bradyrhizobium and initial studies on the basis for acid tolerance of Rhizobium tropici UMR1899. Can J Microbiol 40:189-207

Gyaneshwar P, Hirsch AM, Moulin L, Chen WM, Elliott GN, Bontemps C, Estrada-de los Santos P, Gross E, dos Reis Junior FB, Sprent JI, Young JPW, James EK (2011) Legume nodulating $\beta$-proteobacteria: diversity, host range and future prospects. Mol Plant-Microbe Inter 24:1276-1288

Hernandez-Lucas L, Segovia L, Martinez-Romero E, Pueppke SG (1995) Phylogenetic relationships and host range of Rhizobium spp. that nodulate Phaseolus vulgaris L. Appl Environ Microbiol 61:2775-2779

Herridge DF, Roughley RJ (1976) Influence of temperature and Rhizobium strain on nodulation and growth of two tropical legumes. Trop Grass 10:21-23

Hirsch AM (1992) Tansley review No. 40. Developmental biology of legume nodulation. New Phytol 122:211-237

Hugenholtz P, Cunningham MA, Hendrlkz JK, Fuerst JA (1995) Desiccation resistance of bacteria isolated from an airhandling system biofilm determined using a simple quantitative membrane filter method. Lett Appl Micro 21:41-46

Iturriaga G, Suárez R, Nova-Franco B (2009) Trehalose metabolism: from osmoprotection to signaling. Int $\mathrm{J}$ Mol Sci 10:3793-3810

Lee HK, LaRue TA (1992) Exogenous ethylene inhibits nodulation of Pisum sativum L. cv Sparkle. Plant Physiol 100:1759-1763

Lima AS, Nobrega RSA, Barberi A, da Silva K, Ferreira DF, Moreira FMS (2009) Nitrogen-fixing bacteria communities occurring in soils under different uses in the Western Amazon Region as indicated by nodulation of siratro (Macroptilium atropurpureum). Plant Soil 319:127-145

Martínez-Romero E, Segovia L, Mercant FM, Franco AA, Graham P, Pardon MA (1991) Rhizobium tropici, a novel species nodulating Phaseolus vulgaris L. beans and Leucaena sp. trees. Int J Syst Evol Microbiol 41:417-426

Mathew JA, Tan YP, Srinivasa Rao PS, Lim TM, Leung KY (2001) Edwardisella tarda mutants defective in siderophore production, motility, serum resistance and catalase activity. Microbiology 149:449-457

Michiels J, Verreth C, Vanderleyden J (1994) Effect of temperature stress on bean-nodulating Rhizobium strains. Appl Environ Microbiol 60:1206-1212

Mietzner TA, Morse SA (1994) The role of iron-binding proteins in the survival of pathogenic bacteria. Annu Rev Nutr $14: 471-493$

Mishra RP, Tisseyre P, Melkonian R, Chaintreuil C, Miché L, Klonowska A, Gonzalez S, Bena G, Laguerre G, Moulin L (2012) Genetic diversity of Mimosa pudica rhizobial symbionts in soils of French Guiana: investigating the origin and diversity of Burkholderia phymatum and other betarhizobia. FEMS Microbiol Ecol 79:487-503

Móron B, SoriaDíaz ME, Ault J, Verroios G, Noreen S, Rodríguez-Navarro DN, Gil-Serrano A, Thomas-Oates J, Megías M, Sousa C (2005) Low pH changes the profile of nodulation factors produced by Rhizobium tropici CIAT899. Chem Biol 12:1020-1040

Moulin L, Munive A, Dreyfus B, Boivin-Masson C (2001) Nodulation of legumes by members of the beta-subclass of proteobacteria. Nature 411:948-950

Muofhe ML, Dakora FD (1998) Bradyrhizobium species isolated from indigenous legumes of the Western Cape exhibit high tolerance of low $\mathrm{pH}$. In: Elmerich $\mathrm{C}$, Kondorosi A, Newton WE (eds) Biological nitrogen fixation for the 21st century. Kluwer Academic Publishers, Dordrecht, p 519

Ohashi Y, Saneoka H, Fujita K (2000) Effect of water stress of growth, photosynthesis, and photoassimilate translocation in soybean and tropical pasture legume siratro. Soil Sci Plant Nutr 46:417-425

Perin L, Martinez-Aquilar L, Paredes-Valdez G, Baldani JI, Estrada-de Los Santos P, Reis VM, Cabellero-Mellado J (2006) Burkholderia silvatlantica sp. nov., a bacterium associated with field-grown sugarcane and maize. Int J Syst Evol Microbiol 56:1931-1937

Pikovskaya RI (1948) Mobilization of phosphorous soil in connection with the vital activity of some microbial species. Microbiol (Mikrobiol) 17:362-370

Pinto FGS, Chueire LMO, Vasconcelos ATR, Nicolás MF, Almeida LGP, Souza RC, Menna P, Barcellos FG, Megías N, Hungria M (2009) Novel genes related to nodulation, secretion systems, and surface structures revealed by a genome draft of Rhizobium tropici strain PRF 81 . Funct Integr Genom 9:263-270

Pueppke SG, Broughton WJ (1999) Rhizobium sp. strain NGR234 and $R$. fredii USDA257 share exceptionally broad, nested host ranges. Mol. Plant-Microbe Inter 12:293-318

Riccillo PM, Collavino MM, Grasso DH, England R, de Bruijn FJ, Aguilar OM (2000) A guaB mutant strain of Rhizobium tropici CIAT899 pleiotropically defective in thermal tolerance and symbiosis. Mol Plant-Microbe Inter 13:12281236

Rodríguez H, Fraga R (1999) Phosphate solubilizing bacteria and their role in plant growth promotion. Biotechnol Adv 17:319-339 
Rodríguez H, Fraga R, Gonzalez T, Bashan Y (2006) Genetics of phosphate solubilization and its potential applications for improving plant growth-promoting bacteria. Plant Soil 287:15-21

Schwyn B, Neilands JB (1987) Universal chemical assay for the detection and determination of siderophores. Anal Biochem 160:47-56

Sheriff DW, Ludlow MM (1984) Physiological reactions to an imposed drought by Macroptilium atropurpureum and Cenchrus ciliaris in a mixed sward. Aust J Plant Physiol 11:23-34

Sprent JI (2007) Evolving ideas of legume evolution and diversity: a taxonomic perspective on the occurrence of nodulation. New Phytol 186:934-946

Streeter JG, Gomez ML (2006) Three enzymes for trehalose synthesis in Bradyrhizobium cultured bacteria and in bacteroids from soybean nodules. Appl Environ Microbiol $72: 4250-4255$

Suárez-Moreno AR, Cabellero-Mellado J, Coutinho BG, Mendonça-Previato L, James EK, Venturi V (2012) Common features of environmental and potentially beneficial plant-associated Burkholderia. Microb Ecol 63:249-266

Suzuki A, Suriyagoda L, Shigeyama T, Tominaga A, Sasaki M, Hiratsuka Y, Yoshinaga A, Arima S, Agarie S, Sakai T, Inada S, Jikumaru Y, Kamiya Y, Uchiumi T, Abe M, Hashiguchi M, Akashi T, Sato S, Kaneko T, Tabata S, Hirsch AM (2011) Lotus japonicus nodulation is photomorphogenetically controlled by sensing the R/FR ratio through JA signaling. Proc Natl Acad Sci USA 108:16837-16842

Van Brussel AAN, Tak T, Wetselaar A, Pees E, Wijffelman CA (1982) Small Leguminosae as test plants for nodulation of Rhizobium leguminosarum and other rhizobia an agrobacteria harbouring a leguminosarum sym-plasmid. Plant Sci Lett 27:317-325

Vandamme P, Goris J, Chen W-M, de Vos P, Willems A (2002) Burkholderia tuberum sp. nov. and Burkholderia phymatum sp. nov., nodulate the roots of tropical legumes. Syst Appl Microbiol 25:507-512

Vincent JM (1970) A manual for the practical study of rootnodule bacteria. Blackwell Scientific Publications, London

Weisskofp L, Heller S, Eberl L (2011) Burkholderia species are major inhabitants of white lupin cluster roots. Appl Environ Microbiol 77:7715-7720

Xie J, Knight D, Legget M (2009) Comparison of media used to evaluate Rhizobium leguminosarum biovar viciae for phosphate-solubilizing ability. Can J Microbiol 55:910-915

Yao W, Byrne R (2001) Spectrophotometric determination of freshwater $\mathrm{pH}$ using bromocresol purple and phenol red. Environ Sci Technol 35:1197-1201

Yeung S-L, Cheng C, Lui TKO, Tsang JSH, Chan W-T, Lim BL (2009) Purple acid phosphastase-like sequences in prokaryotic genomes and the characterization of an atypical purple alkaline phosphatase from Burkholderia cenocepacia J2315. Gene 440:1-8 